The significance and effects of oil ...

$\overline{\text { THE SIGNIFICANCE AND EFFECTS OF OIL INJECTION ON }}$

THE PERFORMANCE OF SLIDING VANE COMPRESSORS.

\author{
M.H. Mkumbwa \\ Dept. of Mechanical Engineering, University of Dar es Salaam. \\ P.O. Box 35131 Dar es Salaam, Tanzania.
}

\begin{abstract}
A computer model of a sliding vane air compressor was used to predict the behaviour of machines having different geometries operating at different conditions. The performance parameters which were calculated by the model were the free air delivery, power input and specific capacity which is defined as the free air delivery per unit of power input.The model also included the study of the effects of oil injection on these mentioned compressor performance parameters. The paper describes the simulation model developed incerporating an analysis of the effects of the oil injected into the compressor on the thermodynamic processes taking place in the compressor cells. Studies were also performed to investigate the effects of varying the inclination of the vanes upon the compressor performance and a comparison is made between a dry machine and a machine injected with oil. Results are presented for a six vane machine fitted with vanes inclined in the range $-30^{\circ}$ to $+30^{\circ}$.
\end{abstract}

\title{
INTRODUCTION
}

Small rotary sliding vane compressors have been used extensively in air compression, refrigeration and automotive air conditioning. These systems have been studied by various investigators ${ }^{[1,2,3,4,5.6]}$. The studies have enhanced the understanding of the operational behaviour of such a machine and have also contributed to the current design improvements. Contrary to reciprocating compressors, rotary sliding vane machines fitted with radially sliding vanes are better balanced machines and capable of operating at higher rotational speeds with less vibrations. The main limitation of sliding vane machines is that of internal 
leakage effects which are normally overcome using oil injection at the expense of the provision of oil injection and oil separation equipments and also the effect on the compressor performance.

Kruse $^{171}$ in 1982, studied the effects of oil injection, barrel rings, and vane tip friction on compressor power requirements. He was capable of controlling the amount of oil injected into the cells and he found that increasing the amount of injected oil reduced the required input torque. The torque was only reduced to a certain minimum before increasing again. Increasing the quantity of oil injected after this point no longer reduced the torque but increased it. The increase in torque when the oil flow rate is substantially increased was explained by the excessive hydrodynamic friction and viscous drag effects which become more pronounced compared with the oil film lubrication effect. Pradip ${ }^{|8|}$ in 1988 conducted an investigation into the power requirement of a rotary sliding vane compressor. He also examined the pressure-volume diagram and the effect of reducing the amount of oil injected into the machine. He found that the reduction of oil injected into the compressor by $25 \%$ caused no major change in the pressurevolume diagram but eliminated over-compression in the sealing arc region.

\section{SIMULATION MODEL}

A compressor simulation model will comprise the following parts:-

i) Compressor geometry.

ii) Thermodynamic analysis of all processes in the cell during operation.

iii) Dynamic analysis of the vanes and their friction effects.

iv) Friction effects of the bearings and end faces of the rotor against the stator.

\section{Analysis of Thermodynamic Processes}

The main part which is considered in this paper is part ii) above which deals with the cell thermodynamics taking into account the oil injection effects on the compressor. The compressor cells are treated in the simulation as small control volumes whose volumes vary with their angular position. The working fluids 
The significance and effects of oil ...

considered are the fluid which is being compressed and oil which is used for lubrication, sealing and internal cooling. These working fluids are considered to enter or leave the cells through the suction and discharge ports or may enter and leave through various leakage paths.

The simulation begins with an initial estimate of the pressure, temperature and mass of the working fluids in a cell at a chosen angular position as a reference. As the rotor turns through a small angular displacement, mass and energy changes are computed and conditions within the cell are updated. The process is repeated for a complete revolution of the rotor and finally the state of the cell contents is compared with the initially chosen values. A convergence is assumed to have been achieved if a close corresponcience exists between the initial values and final values. Flows through the suction and discharge ports and through various leakage paths are treated by simple orifice considerations. Beginning with the basic ideal gas equation:-

$$
p_{c} V_{c}=m_{c} R T_{c}
$$

The expressions for temperature, pressure and mass variations for the air in the control volume are as given by equations (2), (3) and (4) respectively.

$$
\begin{aligned}
& \frac{d T_{c}}{d t}=T_{c}\left(\frac{1}{V_{c}} \frac{d V_{c}}{d t}+\frac{1}{p_{c}} \frac{d p_{c}}{d t}-\frac{1}{m_{c}} \frac{d m_{c}}{d t}\right) \\
& \frac{d p_{c}}{d t}=\frac{1}{V_{c}}\left\{(\gamma-1) \frac{d Q}{d t}-\gamma p_{c} \frac{d V_{c}}{d t}+\gamma R\left(\sum T_{i} \frac{d m_{i}}{d t}-\sum T_{c} \frac{d m_{o}}{d t}\right)\right\} \\
& \frac{d m_{c}}{d t}=\sum \frac{d m_{i}}{d t}-\sum \frac{d m_{o}}{d t}
\end{aligned}
$$

\section{Analysis of the Effect of Oil in the Control Volume.}

The injection of oil into the compressor cells for an existing prototype takes place at an angular position $247^{\circ}$ from TDC which is during the compression process. 


\section{Mkumbwa}

The following assumptions are made;-

- The control volume contains a mixture of oil and air.

- The temperature and pressure of the individual substances are uniform.

- The pressure in the control volume is uniform and equal for both air and oil.

- The oil is incompressible.

Chang ${ }^{121}$ verified that a dry compressor model can represent the behaviour of an oil flooded compressor with reasonable accuracy. However, other workers Peterson and McGahan ${ }^{|\vartheta|}$, Smith and Rudge ${ }^{[10]}$ argue that the presence of oil in single stage machines does not contribute significantly to cooling effects during the compression process but that cooling takes place during ard after the discharge process resulting in aftercooling effects. Thus it has been necessary to develop a simple model to investigate the effects of the presence of oil.

The injected oil mass flow rate depends on the pressure difference between the nominal discharge pressure and the control volume pressure at the point of injection.

$$
\frac{d m_{\text {ril in }}}{d t}=C_{d} A_{\text {sil }} \sqrt{\rho_{o i l}\left(p_{d}-p_{c}\right)}
$$

The flow rate coefficient $C_{d}$ was estimated from the measured total flow rate. The oil is assumed to be mixed with the air homogeneously and in this case its discharge rate is proportional to that of the air.

$$
\frac{d m_{\text {oit out }}}{d t}=\left(\frac{m_{\text {oil max }}-m_{\text {oil min }}}{m_{\text {air max }}-m_{\text {air min }}}\right) \cdot \frac{d m_{\text {air out }}}{d t}
$$

The model assumes that heat transfer between the air and the compressor rotor or stator is negligible. The heat transfer rate from the oil to the air is

$$
\frac{d Q}{d t}=h_{t r} A_{s i r i l}\left(T_{c i l}-T_{c i r}\right)
$$

The oil surface area can be determined by considering that the oil is injected as a uniform spray of spherical droplets. The average diameter of the oil droplets in this 
study depends on the droplet slip velocity and was selected according to Persson ${ }^{1 ! 1}$ as being $40 \mu \mathrm{m}$. It has been assumed that all droplets survive in droplet form during the compression process. This droplet diameter enables the determination of the heat transfer area. Persson also stated that for convective heat transfer between oil spheres and air, without any phase change, the Nusselt number is;

$$
\begin{array}{ll}
\mathrm{Nu}=0.37 \cdot \operatorname{Re}^{0.6} & ;(17<\operatorname{Re}<70,000) \\
\mathrm{Nu}=2 & ;(\operatorname{Re} \leq 17)
\end{array}
$$

From the evaluation of the Nusselt number the heat transfer coefficient between the oil and compressed air was determined.

The general energy equation for the air alone is given by:

$$
\frac{d Q_{u i r}}{d t}=P_{a i r} \frac{d V_{a i r}}{d t}-\left(\sum\left(\dot{m}_{i} H_{i}\right)_{a i r \text { in }}-\sum\left(\dot{m}_{i} H_{i}\right)_{a i r \text { out }}\right)+\frac{d U_{a i r}}{d t}=h_{t r} A_{s o i l}\left(T_{\text {oil }}-T_{\text {air }}\right)
$$

Simila:ly the energy equation for the oil in the control volume is expressed as;

$$
\frac{d Q_{\text {oil }}}{d t}=p_{\text {oil }} \frac{d V_{\text {oil }}}{d t}-\left(\sum\left(\dot{m}_{i} H_{i}\right)_{\text {oil in }}-\sum\left(\dot{m}_{i} H_{i}\right)_{\text {oil out }}\right)+\frac{d U_{c}}{d t}
$$

The air pressure $p_{\text {air }}$ in the cell is assumed to be equal to the oil pressure. i.e $p_{\text {air }}=$ $p_{\text {oil... }}$ The heat exchange between oil and air gives $\left|Q_{\text {air }}\right|=\left|Q_{\text {oil }}\right|$.

It is also known that

$$
\begin{aligned}
V_{c} & =V_{a i r}+V_{c i t} \\
\frac{d V_{c}}{d t} & =\frac{d V_{a i r}}{d t}+\frac{d V_{o i l}}{d t}
\end{aligned}
$$

Since oil is incompressible

$$
\begin{gathered}
V_{\text {oil }}=\frac{m_{\text {oil }}}{\rho_{\text {oil }}} \\
\frac{d V_{\text {oil }}}{d t}=\frac{1}{\rho_{\text {sil }}} \frac{d m_{\text {oil }}}{d t}
\end{gathered}
$$

The rate of change of mass of oil in the cell is given by 


$$
\frac{d m_{\omega_{\text {ill }}}}{d t}=\frac{d m_{\text {oil in }}}{d t}-\frac{d m_{\text {oil out }}}{d t}
$$

Integrating equation (14) gives

$$
m_{\text {sil }}=\sum m_{\text {oil in }}-\sum m_{\text {sil out }}+M_{\text {oil }}
$$

where $\mathrm{M}_{\mathrm{sil}}$ is the initial mass in the control volume at time $\mathrm{t}=0$.

The differential equations (1) to (14) were solved simultaneously by using the Runge-Kutta numerical method so as to determine the cell thermodynamic properties during a complete compressor cycle. The initial conditions for the solution were for a cell whose trailing vane had just cleared the discharge port, i.e. when the leading vane was at a position,

$$
\theta=\theta_{c}-\left(360-\beta_{4}\right)
$$

from the Top Dead Centre. The cell pressure was assumed to be the discharge pressure while the cell temperature was determined by assuming isentropic compression from the suction conditions. The initial mass in the cell was then evaluated from the ideal gas equation.

\section{CALCULATED RESULTS}

\section{Effects of Injected Oil on Cell Properties.}

Figures 1.0, 2.0 and 3.0 show the effects of the injected oil on the volume of the cell, cell pressure and temperature, masses in the cell and the pressure-volume diagram for a compressor having vanes inclined at $-20^{\circ}$, radial vanes and vanes inclined at $+20^{\circ}$ respectively.

It can be seen from figures 'a' that the volume occupied by oil in the ce!l for the compressors considered is very small compared with the volume occupied by air. Even towards the end of the compression process, the highest volume ratio of oil to air is about 0.00318 which is approximately $0.32 \%$ of the cell volume just before the discharge port opens. 
The significance and effects of oil ...

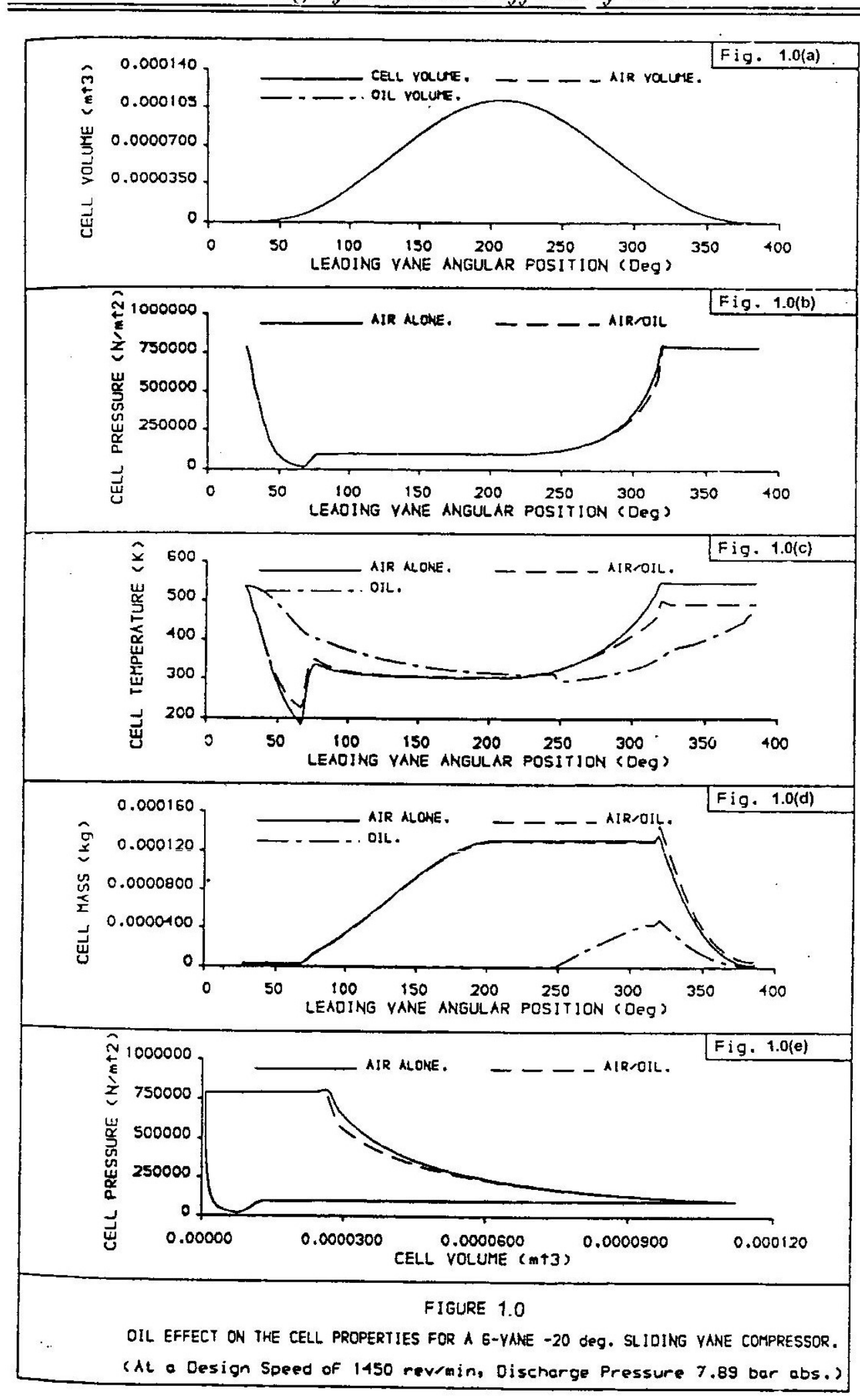




\section{Mkumbwa}

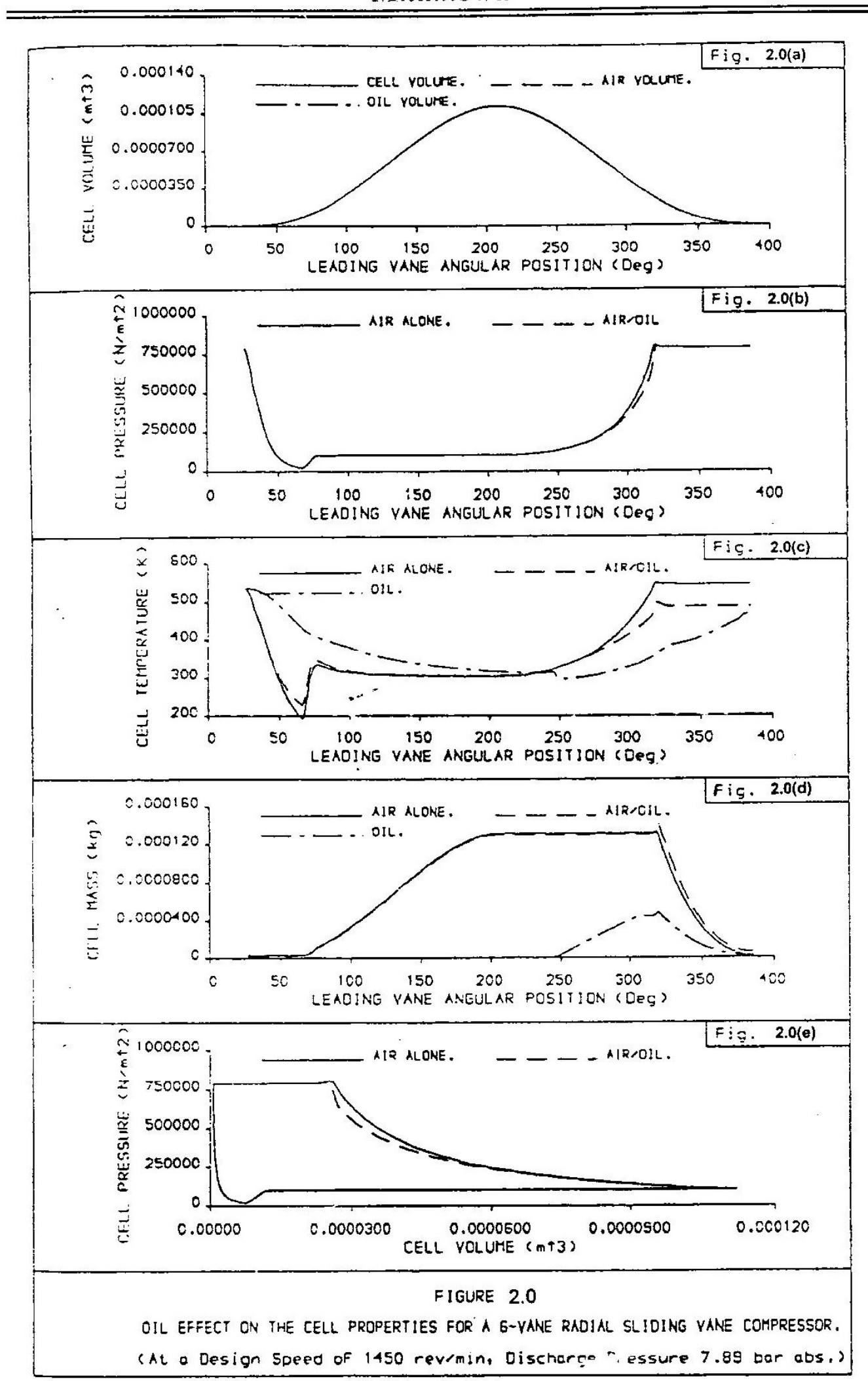


The significance and effects of oil ...

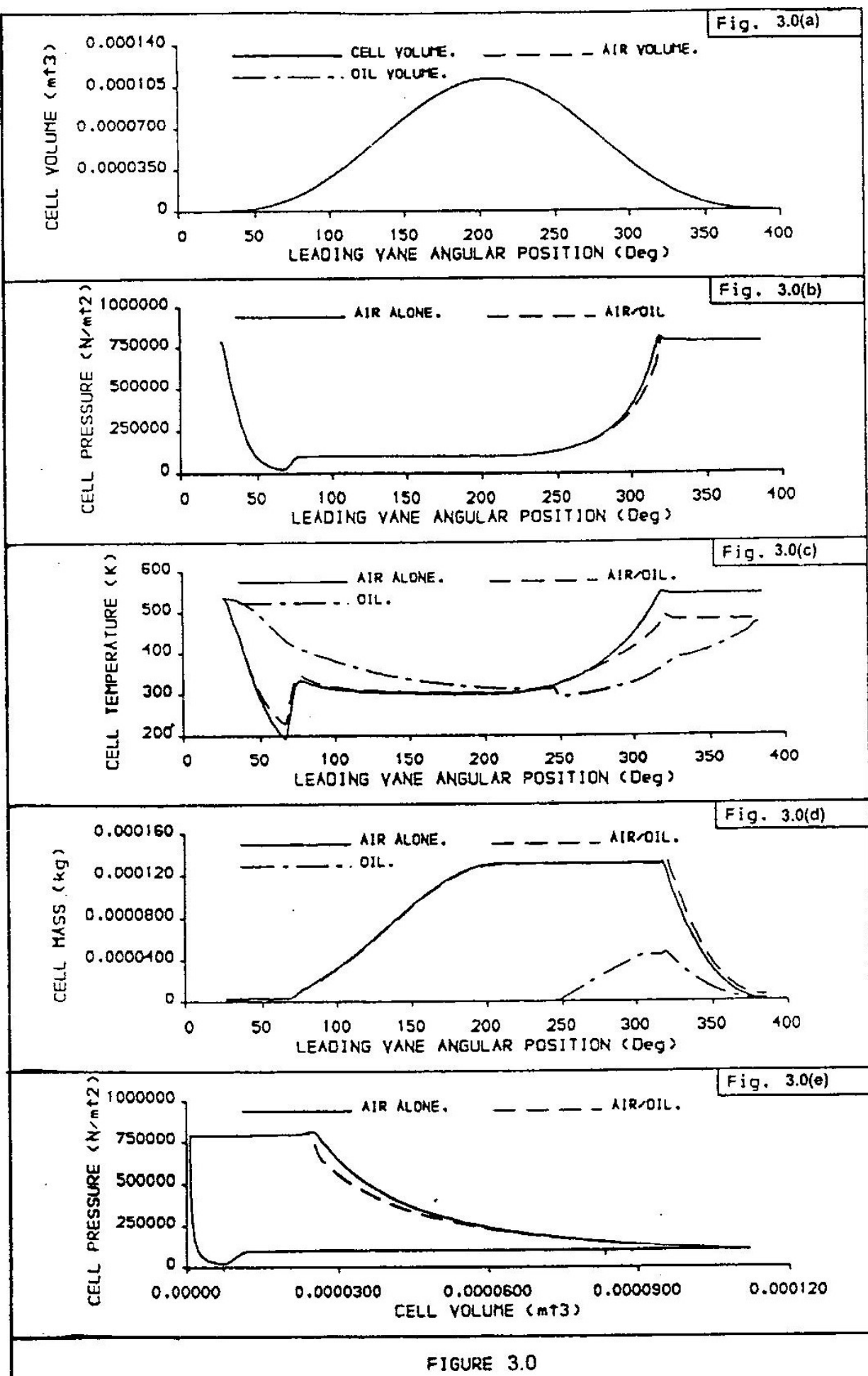

OIL EFFECT ON THE CELL PROPERTIES FOR A 6-YANE 20 deg. SLIDING YANE COMPRESSUR. (At a Design Speed of 1450 rev/min, Diseharge Pressure 7.89 bar abs, ) 


\section{MkuInbwa}

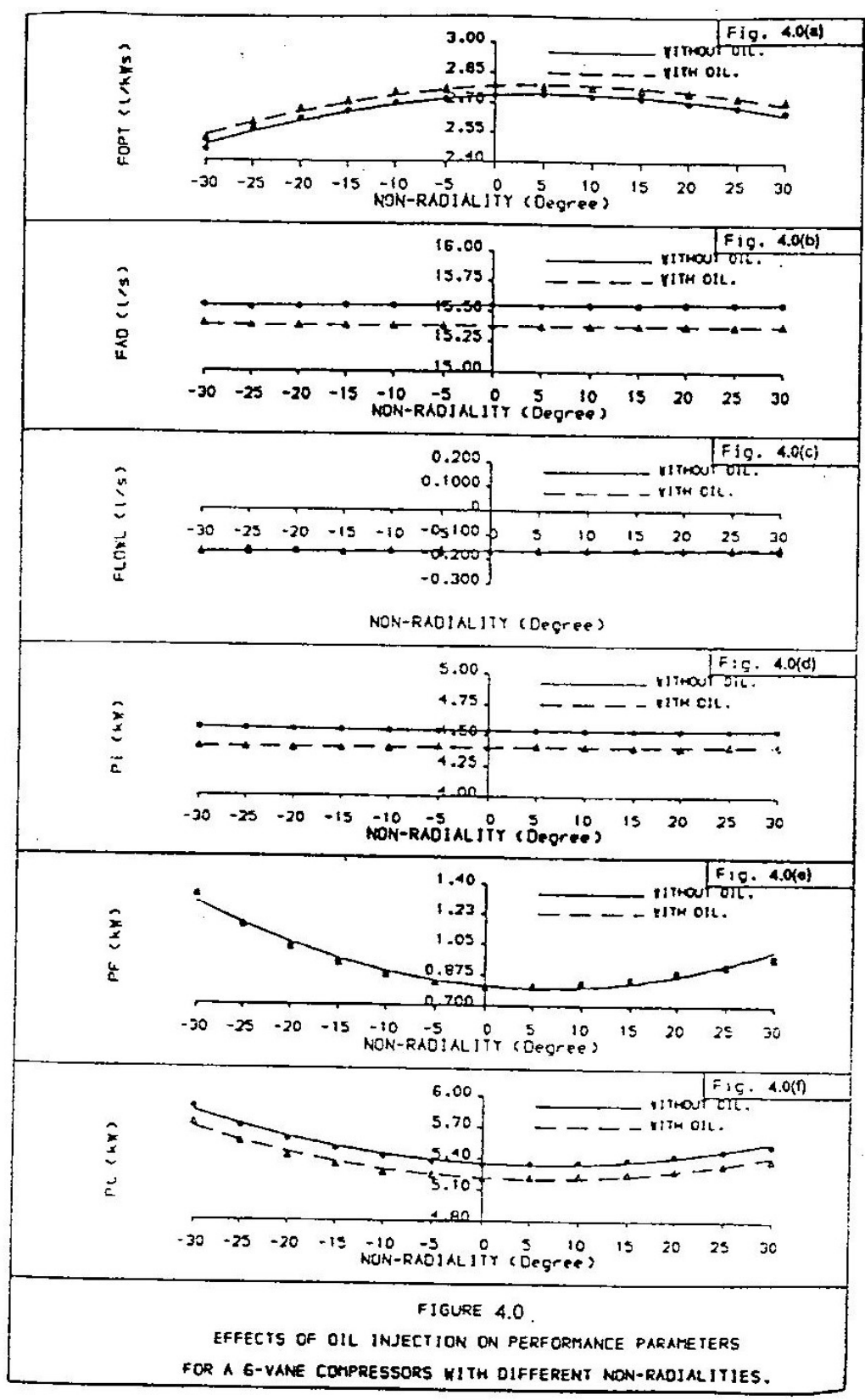

Figures ' $b$ ' show the effect of oil on the cell pressure for a whole cycle. It can be seen that due to the cooling effect of the oil on the air, the air compression takes place at a slightly reduced pressure, in some cases leading to under-compression. This is caused by reduced air temperature as seen from figures ' $c$ '.

Figures ' $c$ ' show the oil and air temperature variations in the cell. Towards the end of the compression process and during the discharge process, the cooling effect of 


\section{The significance and effects of oil ...}

the injected oil has reduced the air temperature by about $50^{\circ} \mathrm{C}$.

Figures 'd' show the air and oil masses induced into the cell during the cycle while figures ' $\mathrm{e}$ ' show the indicated diagrams of the different machines. It is seen from figures 'e' that injection of oil which led to reduced cell pressure during compression, led to the reduction of the compressor work. The reduction of the indicated work was about $4.68 \%$ for all the three types of compressors considered (i.e. $-20^{\circ}, 0^{\circ}$ and $+20^{\circ}$ non-radiality) as shown by figures $1.0,2.0$ and 3.0.

Figure 4.0 $(\mathrm{a}-\mathrm{f})$ show the performance parameters for machines fitted with vane inclined over the range $-30^{\circ}$ to $+30^{\circ}$. Figure 4.0 (a) shows the variation of the specific capacity (FOPT) for dry machines as compared with machines injected with oil. The figure shows that the specific capacity for machines injected with oil is higher by about $1.96 \%$ throughout. FOPT is the ratio of free air delivery (FAD) to the total compressor power $\left(\mathrm{P}_{\mathrm{l}}\right)$. It has been shown in figures $1.0(\mathrm{e}), 2.0(\mathrm{e})$ and $3.0(\mathrm{e})$ and also in figure $4.0(\mathrm{~d})$ that the injection of oil in sliding vane machines reduces the indicated power of the compressor and hence the total power required by the compressor. Since FAD has only been reduced by $1.2 \%$ due to the effect of oil injection, the reduction in the indicated power is the factor which is most responsible for the change in the compressor specific capacity. Overall it is apparent that the effects of oil injection are the same for all vane inclinations.

\section{CONCLUSIONS}

The author has demonstrated to have developed a comprehensive computer simulation model which is able to predict the behaviour of a dry or oil flooded rotary sliding vane air compressor. The model has successfully predicted the effects of oil injection in a given machine and has demonstrated that at constant operating conditions the change in the vane inclination has the same effect upor the compressor performance. The model has been validated experimentally by the author in his previous work ${ }^{|6|}$.

The paper has also shown that injection of oil leads to a reduction in the cell pressure during the compression process which results in the reduction of the compressor indicated work and so enhancing the compressor specific capacity. 


\section{Mkumbwa}

NOMENCLATURE

\begin{tabular}{|c|c|}
\hline$A_{\text {oil }}$ & Injection flow area, $\mathrm{m}^{2}$ \\
\hline$A_{\text {seil }}$ & Injected oil heat transfer surface area, $\mathrm{m}^{2}$ \\
\hline $\mathrm{C}_{\mathrm{d}}$ & Oil flow rate coefficient \\
\hline$h_{\mathrm{ur}}$ & Heat transfer coefficient, $\mathrm{kJ} / \mathrm{m}^{2} \mathrm{~K}$ \\
\hline $\mathrm{m}$ & Mass flow, $\mathrm{kg}$ \\
\hline $\mathrm{p}$ & Pressure, $\mathrm{N} / \mathrm{m}^{2}$ \\
\hline $\mathrm{H}$ & Specific enthalpy, $\mathrm{kJ} / \mathrm{kg}$ \\
\hline$p_{c}$ & Cell pressure, $\mathrm{N} / \mathrm{m}^{2}$ \\
\hline$P_{i r}$ & Frictional dissipation of the sliding vane, $\mathrm{kW}$ \\
\hline $\mathrm{P}_{\mathrm{i}}$ & Indicated power, $\mathrm{kW}$ \\
\hline$P_{1}$ & Total power (sum of $\mathrm{P}_{\mathrm{i}}$ and $\mathrm{P}_{\mathrm{tr}}$ ), $\mathrm{kW}$ \\
\hline Q & Heat transfer, J \\
\hline $\mathrm{T}$ & Temperature, $\mathrm{K}$ \\
\hline TDC & Top Dead Centre \\
\hline U & Internal Energy, J \\
\hline V & Volume, $\mathrm{m}^{3}$ \\
\hline$\rho_{\text {oil }}$ & Oil density, $\mathrm{kg} / \mathrm{m}^{3}$ \\
\hline
\end{tabular}

Subscripts

$\begin{array}{llllll}c & \text { cell } & \text { d } & \text { discharge } & \text { i } & \text { in } \\ \text { o } & \text { out } & \text { fr } & \text { friction } & & \end{array}$

\section{REFERENCES}

1. Ooi, K. T., Geometrical Optimization of Rotary Sliding Vane Air Compressors. Ph.D. Thesis University of Strathclyde, 1989.

2. Chang, K. Y., A Theoretical and Experimental Study of an Oil-Flooded Rotary Sliding Vane Compressor., Ph.D. Thesis Vols. 1 and 2, University of Strathclyde, 1983.

3. Tromblee, J. D., Performance Analysis of a Sliding Vane Rotary 
The significance and effects of oil ...

Compressor for a Household Refrigerator/Freezer., Proceedings of the 1984 Purdue Compressor Technology Conf., pp.40-45.

4. Edwards, T. C. and McDonald, A. T., Analysis of Mechanical Friction in Rotary Vane Machines Proceedings of the 1972 Purdue Compressor Technology Conf., pp.250-262.

5. Tramschek, A.B. and Mkumbwa, M.H., Mathematical Modelling of Radial and Non-radial Rotary Sliding Vane Compressors., Proceedings of the 1996 International Compressor Engineering Conference at Purdue, USA.

6. Mkumbwa, M.H., Simulation and Geometrical Optimization of Radial and Non-radial Rotary Sliding Vane Air Compressors., Ph.D. Thesis University of Strathclyde, 1995.

7. Kruse, H., Experimental Investigation on Rotary Vane Compressors., Proceedings of the 1982 Purdue Compressor Technology Conf., pp.382388.

8. Pradip, K. P., Rotriy Compressor: PV-Diagram and Investigation into Power Requirements., Proceedings of the 1988 Purdue Compressor Technology Conf., pp.141-145.

9. Peterson, C. R. and McGahan, W. A., Thermodynamic and Aerodynamic Analysis Methods for Oil Flooded Sliding Vane Compressors. Proceedings of the 1972 Purdue Compressor Technology Conf., pp.1-8.

10. Smith, D. G. and Rudge, P. J., Pressure-Volume Diagrams for Sliding Vane Rotary Compressors Proceedings of the Institution of Mechanical Engineers, Vol. 184, Pt3R,1969-1970, pp. 159-166.

11. Persson, J. G., Heat Exchange in Liquid-Injected Screw Compressors., VDI Berichte Nr. 640, pp.121-135. 